\title{
HOW INFLUENTIAL ARE ACCOUNTANTS IN THE IMPLEMENTATION OF AN INTEGRATED SYSTEM? A CASE STUDY IN AN IRISH PUBLIC SECTOR ORGANISATION
}

\author{
Julie Griffin \\ Dublin City University \\ and \\ Sylvia Dempsey \\ Cork Institute of Technology
}

\begin{abstract}
There is a dearth of literature on the implementation of integrated computerised systems in the public sector and the role of accountants in the implementation process. This paper explores the influence of accountants in the implementation of a centralised debtors system in an Irish public sector organisation. It reveals accountants as instrumental figures in the implementation and a strong contributing factor to its success. Their traditional skills in accounting and analysis, combined with their modern softer skills of communication, team-playing and leadership, their strong business acumen and their knowledge of technology, made them valuable members of the implementation team.
\end{abstract}

\section{INTRODUCTION}

An integrated system is one of the modern information technology approaches an organisation can use to improve its competitiveness by improving efficiency and delivering a better service to customers. Integrated systems have been widely adopted by organisations in the private sector and a mass of literature is available describing the different factors required to successfully implement integrated systems in that sector. However, their implementation is still a new phenomenon in the public sector, with very little written in academic journals (Kumar, Maheshwari and Kumar, 2002; Kavanagh and Hoekstra, 2004; Botta-Genoulaz 
and Millet, 2006). To quote Botta-Genoulaz and Millet, this is a 'new area' in the service sector and 'there is little theoretical research on the topic' (2006, p. 203).

Also very little has been written on the influence of accountants in the implementation of integrated systems. There is a limited amount of existing research on 'how opportunities are opened up' (Scapens and Jazayeri, 2003, p. 201) to accounting by the implementation of integrated systems. Granlund and Malmi (2002) examined the impacts which the introduction of integrated systems can be expected to have on management accounting. Subsequently, others have called for further research on the relationship between integrated systems and accountants' expertise (Hunton, 2002; Bhimani, 2003; Granlund and Mouritsen, 2003; El Sayed, 2006). O'Mahony and Doran describe integrated systems as 'one of the major contributors to the change in the role of the management accountant' $(2008, p .114)$. As well as this, Scapens and Jazayeri (2003) call for more case study research on the implementation of integrated systems. This study aims to instigate a discussion on the influence of accountants in the implementation of an integrated system in the public sector. The case study chosen is the implementation of an integrated centralised debtors system for the water service of a local authority in Ireland.

The format of the paper is as follows: the first section examines existing literature relating to this research. The main outcome of this section was the formation, from the available literature, of a critical success factors framework which is required to ensure the satisfactory implementation of an integrated system. The research design is then discussed. This is followed by a profile of the case study, namely the introduction of a new centralised debtors system for the water service of a county council. It depicts the tendering, development and implementation processes and the people involved at each stage. The final section analyses the information gathered and highlights the importance of the accountants' influence in each of the ten critical success factors as outlined in the study. It concludes that the influence of accountants in the implementation of an integrated system is as the role of leader, champion, team player, communicator and provider of information and business knowledge.

\section{LITERATURE REVIEW}

The information system of an organisation is integrated if the systems and databases used in the various units of an organisation are tied together into one overall system. Governments are wary of the risks and challenges that come with implementing integrated systems (Madden and Miranda, 1998). The Irish government spent millions on a health service payroll and personnel system (called PPARS) only to have it halted due to systems errors and huge escalating costs (Hunter, 2005). The Comptroller and Auditor General claimed that part of the reason for the failed system implementation was due to not properly defining the business needs of the health sector organisation. It is imperative that the organisation is aware of the risks and implications of implementing an integrated system. Some of the risks cited in existing literature are user acceptance, soaring costs, organisational change, project scope change, availability and retention of skilled people, integration with other legacy systems and the capability of the organisational infrastructure to contend with the new technology 
How Influential Are Accountants in the Implementation of an Integrated System?

(Miranda, 1999; Umble and Umble, 2002; Botta-Genoulaz and Millet, 2006). Ten success factors, critical for the attainment of the benefits of an integrated system and the minimisation of the identified risks, were synthesised from the prior literature. They are outlined in the model presented in Figure 1. This model provides a useful framework to explore the main findings from this empirical research.

FIGURE I: CRITICAL SUCCESS FACTORS FOR A SUCCESSFUL IMPLEMENTATION OF AN INTEGRATED SYSTEM

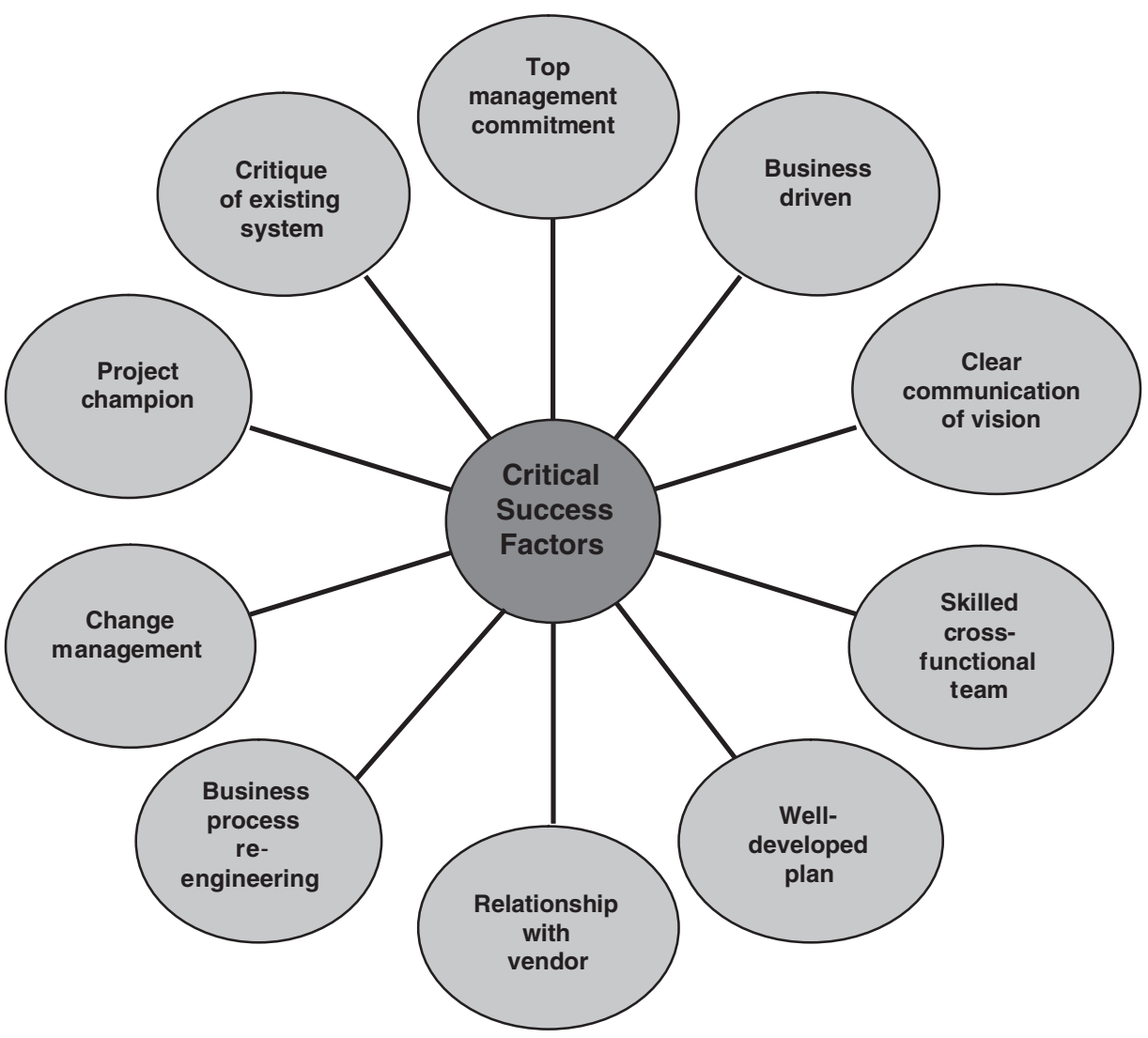

\section{Top Management Commitment}

The enormous process of integration can only be achieved if top management give the project priority. This top management support strengthens the commitment of all employees in the enterprise (Bingi, Sharma and Godla, 1999; Gurd, Smith and Swaffer, 2002; Nah, Zuckweiler and Lee-Shang Lau, 2003). As a demonstration of this commitment, top management must be seen to allocate the necessary resources, such as time, money and personnel, to the project (Gurd et al., 2002; 
Nah et al., 2003; Nah and Delgado, 2006). The commitment of top 'finance' management is not very well researched. However, it is recognised that in organisations where the accountants and the rest of the management team share a view of the importance of the involvement of the accountants, the role of the accountants in change management is maximised. These organisations should ensure that they recruit accountants with a broad base of business and technical skills (Chenhall and Langfield-Smith, 1998; Caglio, 2003; Dempsey and Vance, 2006).

\section{Business Driven}

If an organisation installs an enterprise resource system (ERP) system without looking at its impact on the way the business operates, 'the dream of integration can quickly turn into a nightmare', according to Davenport (1998, p. 122). Therefore, as well as being technology driven, it is essential to the success of the project that it is business driven (Shanks, Parr, Hu, Thanasankit and Seddon, 2000; Nah and Delgado, 2006). The physical location of the accountants comes into play here as well. If accountants are located out in the units that they service then they have a better chance of acquiring both 'a good understanding of the business' and 'the confidence of managers' (Pierce and O'Dea, 2003, p. 279). This allows the accountants to become a key part of the team required to drive change.

\section{Clear Communication of the Vision}

Clear communication of the business vision is critical to ensuring all individuals within the organisation understand how their activities support the organisational goals, or else they will not understand why the integrated system is being implemented (Legare, 2002; Nah and Delgado, 2006). Communication should be open and honest with employees knowing that any feedback they provide regarding the integrated system will be managed and acted upon (Nah et al., 2003; Loh and Koh, 2004; Nah and Delgado, 2006). Accountants are often seen as the best people to present analytical information and update users and management on the plans for how the organisation will function in the future.

\section{Skilled Cross-Functional Team}

The project team should be a skilled cross-functional team with a healthy balance of involvement by top management, technologists and users (Kumar et al., 2002). They should be familiar with the business functions and products, so that they have the ability to make decisions and to rethink business processes in order to improve the current system (Umble and Umble, 2002; Loh and Koh, 2004). When new systems are introduced, accountants play a very important role liaising between the users and the computer specialists (Tsay, 1992). Accountants today need skills and knowledge that allow them to work as multi-disciplined 
How Influential Are Accountants in the Implementation of an Integrated System?

managers across organisations, communicating winning strategies and controlling implementation and performance (Allott, Weymouth and Claret, 2001). If they have these skills they will be an important part of a 'change' team.

\section{Well-Developed Plan}

If a well-developed work and resource plan does not precede a new system's implementation, the implementation costs can soar and the implementation period can run on for much longer than anticipated (Miranda, 1999; Davenport, 2000; Legare, 2002; Scapens and Jazayeri, 2003). Research has found that implementation times can vary from six months to four years (Motwani, Subramanian and Gopalakrishna, 2005). The accountants' knowledge of planning and control, along with their positioning on-site with the users, means that the accountants can help progress the project, meet deadlines and finally assist in training.

\section{Close Working Relationship with the Vendor}

A close working relationship between the vendors, consultants and project teams is also vital for information sharing and the successful implementation of an integrated system (Holland and Light, 1999; Nah et al., 2003; Nah and Delgado, 2006). The project team should include a good mix of internal staff and external consultants. The accountants can liaise with the vendor in an effective manner. They are often the people who can best express to the vendor the requirements of the end users (Carswell, 2002).

\section{Business Process Re-Engineering}

The business process re-engineering factor involves identifying the organisation's business processes that add value to the organisation's activities (Manganelli and Klein, 1994; Halachmi and Bovaird, 1997). According to some researchers, a company that implements an integrated system must largely accept the suppliers' assumptions about management philosophy and business practices and the company must reengineer existing processes and procedures to conform to those assumptions (Umble and Umble, 2002; Scapens and Jazayeri, 2003). However, other researchers argue that if all competitors adopt the same integrated systems they will theoretically have the same business processes and best business practices (Davenport, 1998; Doran and Walsh, 2004; Rikhardsson and Kraemmergaard, 2006).

\section{Change Management}

It has been found that change management is essential during a systems implementation and that during the change period formal training and education 
should be provided to help users understand how their job roles may be changed with the new integrated system (Umble and Umble, 2002; Loh and Koh, 2004; Nah and Delgado, 2006). Also, a help desk or online user manual should be available (Nah et al., 2003; Loh and Koh, 2004; Nah and Delgado, 2006). According to the extant literature, accountants play a key role in ensuring that the users understand their job roles and get a system they need (Allott et al., 2001).

\section{Project Champion}

The project champion is critical to drive consensus and to oversee the entire life cycle of the implementation (Loh and Koh, 2004; Motwani et al., 2005; Nah and Delgado, 2006). Some accountants do not view championing projects as part of their role; they consider their role to be that of managing traditional finance functions (Chenhall and Langfield-Smith, 1998). However, others wish to move away from the traditional accounting roles and start 'leading the agenda' (Dempsey and Vance, 2006, p. 37). Adam and O'Doherty (2000) found that out of fourteen firms they surveyed that were implementing ERP systems, nine were headed and championed by either a financial director, a controller or an accountant. In a survey carried out by Doran and Walsh (2004), over 70 per cent of respondents held the title of Financial Controller/Financial Accountant, who, in line with other researchers' suggestions, 'may have been the ERP project champions in their organisations' (Doran and Walsh, 2004, p. 31). Other case studies also indicated that the finance department was the main initiator of new information systems (Bingi et al., 1999; Hyvonen, 2003; Motwani et al., 2005).

\section{Critique of Existing System}

The more complex the current information technology (IT) architecture, the more organisational and technological change required for the new integrated system. By examining the existing legacy systems of an organisation, some of the potential problems of the new system can be predetermined. This feed forward information will minimise any reconfiguration at a later stage (Holland and Light, 1999; Nah and Delgado, 2006). The accountants can play an influential role in documenting and highlighting the problems of the existing systems and in providing business solutions to overcome these problems. These ten 'critical success factors' were used as the framework for the case study examined in this paper.

\section{RESEARCH APPROACH}

One of the researchers was working in the council when the need to implement a new integrated system was announced. The researchers decided to use this opportunity to carry out an extensive exploratory piece of research on the influence of accountants in the implementation of an integrated system in the public 
How Influential Are Accountants in the Implementation of an Integrated System?

sector. Multiple sources of evidence were gathered by participation, observation, interview and document review. Both semi-structured and unstructured interviews were carried out. The unstructured interviews involved meetings with various people throughout the organisation, while the four semi-structured interviews were carried out with those directly involved in the project: the head of finance, the senior executive officer (SEO) of finance, the SEO of information communication technology (ICT) and the financial accountant. Throughout the interviews openended questions were used, allowing the interviewees to expand their opinions about events. These interviews were taped and transcribed in full. The researchers had access to internal documents, such as tender documents, e-mails, minutes of meetings, proposals, progress reports, presentations, CD-ROMs and training manuals.

\section{CASE STUDY}

The remit of the county councils and city councils in Ireland is to supply water and sewage facilities, housing, roads, planning, public libraries and fire services in their area. Each county council and city council is headed by the county or city manager. The county council used as a case in this study is divided into three divisions: north, south and west. These are supported by service directorates: personnel, finance, ICT, corporate affairs, and estates and economic development. Each of these service directorates has a head of department to which a senior executive officer (SEO) reports. This case study focuses on the implementation of a centralised debtors system for the water service of a county council. Prior to the centralisation of the council's debtors, the council operated the debtors legacy systems and JD Edwards (JDE) financial management system. The debtors legacy systems held all the customers' details while JDE was used to produce the annual financial statements. Despite JDE being an ERP system, the debtors legacy systems were not interfaced with the JDE Accounts Receivable (AR) module. The reason given for this was the limited functionality of JDE AR.

The finance department completed a needs assessment at the end of 2005. It revealed three major deficiencies. Firstly, the existing debtors legacy systems were becoming dated and no longer provided enough information for management or customers' purposes. Secondly, the lack of integration led to information reconciliation problems at month-end. Thirdly, the debtors legacy systems operated at a divisional level as opposed to an overall organisational level. To prepare a county-wide report, the reports from the three individual divisions would also have to be collated by the financial accountants. All of these issues drove the need for a new integrated centralised system.

The needs assessment provided the council with a clearer vision of what it required from a new system. The next step was to identify and evaluate possible solutions. Four solutions were identified. The first possible solution identified was to outsource all the billing and receipting of water to an external contractor. This was rejected as the council was anxious to modernise its debtors systems for all streams of income and by doing it in-house for one stream of income this would 
make it easier and cheaper to subsequently include the other streams. The second option was to transfer the water debtors legacy systems over to the accounts receivable (AR) module of JDE. However, the functionality of the JDE AR module was inferior to that of the current debtors legacy systems. The financial accountant stated that:

The JDE AR module was not selected because it was not appropriate; the functionality of AR was not sufficient or robust enough to support an Irish local authority without considerable and costly modifications. It was more suited to routine billing of a private company.

The third option identified was to interface the existing debtors legacy systems with the JDE General Ledger (GL). However, this would not address the inadequacies in the debtors legacy systems that would need to be addressed. Interfaces would also have to be built into the JDE GL. It was felt that this investment would not be worth the cost involved and other options might have better functionality. The fourth option, and the solution which was decided upon, was to implement a centralised billing and receipting system known as the centralised debtors system. This would replace the three existing debtors legacy systems and would be interfaced with the JDE financial management system. As well as being the most efficient and cost effective solution, it was also seen as part of a modernisation agenda for the council.

The council then had to tender, procure and implement a robust centralised debtors system. A timeline (set out in Figure 2) was established for the tender and procurement process.

The formal tenders were assessed by the tender assessment team, consisting of a finance officer, three accountants and two IT specialists. Upon completion of this assessment the decision was made to award the contract to " $\mathrm{A}$ ". The centralised debtors system was to be up and running eight months later.

FIGURE 2: THE COUNTY COUNCIL'S TENDERING PROCESS TIMELINE CHART

\begin{tabular}{|c|c|c|c|c|c|c|c|}
\hline \multirow[b]{2}{*}{ Tasks } & \multicolumn{7}{|c|}{ Months } \\
\hline & $\begin{array}{c}\text { Mar } \\
2006\end{array}$ & $\begin{array}{c}A p r \\
2006\end{array}$ & $\begin{array}{l}\text { May } \\
2006\end{array}$ & $\begin{array}{c}\text { Jun } \\
2006\end{array}$ & $\begin{array}{c}\text { Jul } \\
2006\end{array}$ & $\begin{array}{c}\text { Aug } \\
2006\end{array}$ & Sep 2006 \\
\hline \multicolumn{8}{|c|}{ Pre-Qualification Questionnaire } \\
\hline \multicolumn{8}{|l|}{ Tender Document } \\
\hline \multicolumn{8}{|c|}{ Opening of Tender Document } \\
\hline \multicolumn{8}{|c|}{ Assessment of Tender Document } \\
\hline \multicolumn{8}{|l|}{ Vendor Interviews } \\
\hline Demonstration & & & & & & & \\
\hline Site Visit & & & & & & & \\
\hline Contract Signed & & & & & & & \\
\hline
\end{tabular}


How Influential Are Accountants in the Implementation of an Integrated System?

Once the contract with " $\mathrm{A}$ " was finalised, a steering committee and a project team were established. The steering committee, comprising of the head of finance, the head of ICT and the general manager of " $\mathrm{A}$ ", agreed project schedules and also agreed to resolve any critical issues that arose during the lifetime of the project. The project team was headed by two project leaders - the SEO (Finance) and SEO (ICT) - and was a multi-functional team consisting of ICT staff, a financial accountant, a contract accountant and a user of the debtors legacy systems. According to the SEO (ICT), 'the experience of each of these project members was required'. The remit of the project team was to liaise with the implementation and development team from " $\mathrm{A}$ ". It would manage the project on a day-to-day basis and report regularly to the steering committee.

" $\mathrm{A}$ " created the project initiation document, which it distributed to the steering committee and the project leaders. This document described the proposed centralised debtors system as a centralised system comprising the following software modules: sales ledger, cash management, e-receipts and a water billing system. These modules would be fully integrated and interfaced with the JDE GL module. The water billing system would be tailored specifically for the complexity of water billing in the council. This document was approved by the head of finance before the detailed project plan covering all the projects activities was produced by "A". This outlined the project's key stages as system design, interfaces, configuration, training, functionality and user acceptance testing, data conversion testing and live build, and go live system. It also presented a timeline for these key stages (see Figure 3).

Familiarisation meetings were held between the " $\mathrm{A}$ " team and the relevant members of the council's project team. "A" specifically requested to meet the accountants to get an understanding of the JDE chart of accounts and water service accounting procedures. The council's ICT department ordered the required servers. " $\mathrm{A}$ " commenced server configuration and installed the server operating system. " $\mathrm{A}$ " did all the testing required and once it and the project team were satisfied that there were no problems, the hardware and software were put in place and the training commenced.

FIGURE 3: THE COUNTY COUNCIL'S IMPLEMENTATION TIMELINE CHART

\begin{tabular}{|l|c|c|c|c|c|c|c|c|c|}
\hline \multirow{2}{*}{ Stages } & \multicolumn{7}{|c|}{ Months } \\
\hline & Sep & Oct & Nov & Dec & Jan & Feb & Mar & Apr & May \\
System Design \& Interfaces & 2006 & 2006 & 2006 & 2006 & 2007 & 2007 & 2007 & 2007 & 2007 \\
System Configuration & & & & & & & & & \\
Training & & & & & & & & \\
Functionality and User Testing & & & & & & & & & \\
Conversion Testing and Live Build & & & & & & & & & \\
Go Live & & & & & & & & & \\
\hline
\end{tabular}


User training in the council was based on 'train-the-trainers'. The SEO (Finance) selected two people - the manager of the new centralised debtors system and a finance clerk - to be trained as trainers. " $\mathrm{A}$ " came on-site over eight weeks and trained the project team members and the two trainers. The trainers, with the assistance of the accountants, subsequently trained the users in the finance department and divisions. " $\mathrm{A}$ " provided end-user training materials during the training sessions. The trainers and the accountants also produced their own user manual, which was placed on the council's shared server. After training was completed, functionality and user acceptance testing commenced. The accountant and the centralised debtors system users carried out a number of tests on the system to ensure it met the council's requirements for billing and receipting procedures. The accountant subsequently tested the interface between the centralised debtors system and JDE GL. The results were all found to be satisfactory.

When the debtors legacy systems were closed for the year ended 2006, the accountants gave the closing debtors' balances to " $\mathrm{A}$ ", who transferred them into the live centralised debtors system. The accountants confirmed that the figures in the live centralised debtors system agreed with the closing figures recorded on the annual financial statements for 2006. The receipts for early 2007 were recorded on the old debtors legacy system initially and transferred to the centralised debtors system in March 2007. This transfer was again done once the accountants had agreed that the receipts recorded on the debtors legacy system agreed with the receipts recorded on the JDE GL. Eventually all the data were converted to the live centralised debtors system. The council's accountants, ICT personnel and key users tested the functionality, accuracy and interfaces of the centralised debtors system. They were satisfied that the system met the organisation's needs and was ready to 'go live'. The system went live and issued its first set of water bills in May 2007. The future vision of the council is to consolidate the multiple debtors legacy systems that exist for its other services into the single centralised debtors system and also to allow the public to view their accounts and pay their water bills online.

\section{FINDINGS FROM THE CASE RESEARCH}

The main findings described below from the empirical research are examined with respect to the ten critical success factors in Figure 1, focusing mainly on where and how the accountants influenced each of these factors.

Amongst others, Nah et al. (2003) and Nah and Delgado (2006) stress the importance of top management commitment in the process of integration. In this case study, top management commitment was evident throughout the implementation process. The interviewees talked about the availability of monetary support; more importantly, they saw the provision of human resources from ICT and finance as the ultimate confirmation of the commitment of management to this project:

Top management supported the project and assisted by making key ICT and finance staff available. This project was always given priority. (Financial accountant) 
This provision of key personnel, particularly from ICT and finance, helped build and maintain the priority of the project throughout the organisation.

In their research, Davenport (1998), Miranda (1999) and Motwani et al. (2005) emphasise the need for integrated systems implementations to be business driven. It is clear from this research that the case for this new centralised debtors system was not just 'technology' or 'accounting' driven, it was 'business' driven. The head of finance described the project as part of 'the modernisation phase within the council'. He believed it was critical to improving customer service and becoming more efficient. The council, in its wish to be viewed as a modern service provider, wanted its customers to be able to make payments online and view their accounts online. As a result, collection levels and customer credit ratings would be improved. The head of finance was responsible for developing the business case for the new system and communicating it to the various management levels within the organisation. Pierce and O'Dea (2003) note that moving the accountants out of the back office and into the business units improves the business acumen of the accountants. One of the significant advantages for the council in the implementation process was the physical relocation of the accounting team out of the finance office and into the business divisions for a portion of each week. The accountants assisted the divisions with financial accounting queries and in return gained valuable knowledge of the business, its problems and its information requirements. The head of finance claims that the council's accountants successfully 'used this business acumen to establish where the project should be going and they were and are viewed within the council as being business-oriented'.

According to Legare (2002), clear communication of any new vision or plan is needed from the beginning and throughout the implementation period. Communication of the business vision of the new centralised debtors system was ongoing in the council and it was mainly carried out through meetings, e-mails, presentations and training of key users. Clear communication of individuals' roles and responsibilities were communicated by the SEO (Finance) and SEO (ICT) to the specific individuals concerned. This ensured that each individual clearly understood their tasks in order to achieve the project's objective of a successfully implemented centralised debtors system. It was the responsibility of the head of finance to communicate the vision of the project to management at regular management meetings. He explained why the council was implementing the new system, described the solution that was selected and its benefits and explained how the council was going to implement it. These presentations won and maintained the support of the management team throughout the systems implementation. The users of the debtors legacy systems were initially resistant to change. According to the SEO (Finance), 'they were quite happy with the systems they had, as they did what they wanted them to do'. The head of finance was instrumental in overcoming this resistance. He explained that the debtors legacy systems did not meet organisational objectives and that the new centralised debtors system would actually free up some of their time to focus on other aspects of their jobs. The business vision was further successfully communicated to users by the accountants during the set-up and training of the new system. It was also the accountants who communicated to the vendors, in a way that they understood, 
the requirements of the new system. This was especially apparent during the systems design and interface implementation stage of the project where the accountants described the billing, receipting and financial reporting requirements of the new system. The need for interpersonal skills, communication skills and knowledge of technological terminology and capability by the accountants were a necessity in doing this and, according to the head of finance:

Communicating to the vendors, in an understandable manner, meant that the excellent communication skills of the accountants were essential to ensuring the success of this project.

The business vision was communicated clearly to the organisation's staff and vendor by the head of finance, the SEO (Finance) and the accountants. The accountants, using their communication skills and close working relationship with the clerical officers in the council, were a vital force in communicating the council's new business vision.

Prior research findings have clearly indicated that successful integrated systems have been implemented by cross-functional and multi-skilled teams (Davenport, 2000; Kumar et al., 2002). The council's project leaders and members were selected because their range of skills and history as strong players in previous 'change' projects made them valuable assets. To quote the head of finance:

The individuals involved had the skills and vision to be able to deliver the integrated billing and receipting system. They were highly motivated and goals- and objectives-focused. They had also delivered in the past on previous county council projects.

The accountants provided the other members of the team with all the financial requirements, such as GL codes on JDE for debtors, bank and income. To do this they had to understand the technology issues. As trainers of the new system, the accountants were also required to have good communication and technological skills. The head of finance said:

The accountants were not expected to be programming gurus but they needed to understand how the systems could work and what they could and could not do.

When the original JDE financial management system was implemented the accountants were not involved, as it was seen to be a purely technological driven project. The consequence of this, according to the head of finance, was that the council spent 'many years having to backtrack, having to balance accounts and making it do what the accountants needed it to do'.

Legare (2002) believes that a well-developed work and resource plan is essential. In this study, the project initiation document was prepared by the vendors and signed by the head of finance. A detailed project plan was prepared by the project team and the vendor. It clearly outlined individuals' roles and time deadlines. According to the head of finance: 
How Influential Are Accountants in the Implementation of an Integrated System?

It outlined the key objectives and goals and the realistic but challenging time scales which to date were met throughout the project.

Progress on the project was reviewed by the project team at weekly meetings and through e-mails and phone calls. The weekly meetings were chaired by the SEO (Finance) and SEO (ICT). They highlighted where individual departments were not meeting their targets. Immediate resolution of any unmet targets was required. Without this process it may not have been a success. The accountants provided the opening water debtors figure for the new centralised debtors system. To do this the accountants worked closely with the three divisions (north, south and west), setting up weekly timetables to be adhered to and carrying out site visits to ensure the debtors legacy systems at the previous year end were closed in a timely manner for the transfer of the water debtors data to the new centralised debtors system. This highlights the importance of the accountants' planning and control skills, along with their position within the organisation, in preparing project plans and monitoring progress. The project team followed well-developed work and resource plans that were drawn up by the project leaders, the accountants and the vendor. They met weekly to ensure these plans were being adhered to. The accountants were key players in the planning and control of the time and money invested in this project.

Holland and Light (1999), Nah et al. (2003) and Nah and Delgado (2006) emphasise the value of a good working relationship with the vendor of the new system. The council recognised this in its tendering and selection process. It required a vendor that could deliver the proposed complex solution. The financial accountant said:

It was crucial for us that it wasn't an 'us and them' solution, it had to be a partnership.

Due to the selected vendor's unique local authority expertise, the level of cooperation throughout the project was first class. Any key requirements that were not specified in the beginning were incorporated into the solution by the vendor at no extra cost within the scope of the original agreement. The vendor viewed the council as an important customer, not just for this project, but also potentially for the future. It saw this as an opportunity to improve its reputation as a systems specialist in the public sector market. The vendor was available to the council by telephone or e-mail when required. It carried out on-site visits and provided onsite training. It was also present to help the accountants with the testing of the new centralised debtors system. According to the financial accountant:

The close working relationship was evident from the availability of vendor personnel during specification/workshop days, together with their availability to answer any concerns on a daily basis to personnel of the council where necessary.

Carswell (2002) stated that accountants are often best positioned to liaise with the vendor. This study confirms this statement as the accountants and the SEO 
(Finance) played a major role in passing the information requirements of the key users onto the vendor. According to the head of finance:

If the accountants have a business sense and know the business requirement from the project, then they can be fantastic middlemen explaining to both the vendor and users in layman's terms the solution to the problem.

The accountants clearly explained the water billing and receipting rules to the vendor. It is clear that the close working relationship built by the accountants with the vendor had an impact on the success of the implementation of the system. The head of finance said:

The council needed to look at the ways in which a centralised debtors system could improve its processes. An external vendor could not do this on their own, so it was vital that the accountants, because of their knowledge of the legacy systems, created and maintained a good relationship with the vendor.

Manganelli and Klein (1994) and Halachmi and Bovaird (1997) believe that in order to implement a new integrated system the organisation needs to clearly identify the business processes that add value to its activities. In this study, the accountants' review of the billing and receipting procedures brought to light the non-value-adding activities. By designing a centralised debtors system within the finance department, separate billing and receipting processes carried out in the divisions were eliminated. One standardised method of billing and a set number of standard payment method options were established. The accountants played a major role in the redesign of business processes due to the knowledge and expertise they had acquired from working on-site with the council staff.

All of the literature examined stressed the need for adequate change management (for example, Umble and Umble, 2002; Loh and Koh, 2004; Nah and Delgado, 2006). The changes that came about with the implementation of the new centralised debtors system in the council were managed by the project team. The SEO (ICT) and SEO (Finance) documented the possible risks that could have occurred during the implementation of the system on the centralised debtors system risk register. Some of the risks identified were member(s) of the project team leaving the project team, internal staff resources not being available, a reduction in senior level commitment to the project, delays in developing interfaces, a failure to communicate effectively with local offices, inaccurate information being exchanged between the old system and the new system, user acceptance, testing delays and ICT issues. They then identified possible courses of action, should any of these events occur. A wide range of staff were also trained. This reduced the risk of losing key knowledge if key staff members were to leave. The SEO (Finance) said the users 'grew enthusiastic about the new system' during training when its user friendliness was pointed out to them by the accountants. The user screens are self-explanatory and the manual reconciliations between the different systems were no longer required. These all helped to foster a positive attitude among the users towards learning how to use the new system. The accountants 
How Influential Are Accountants in the Implementation of an Integrated System?

also coordinated and managed the testing of the centralised debtors system. This was evident during the functionality and user acceptance testing, data conversion testing and live build phases. The accountants ensured that the centralised debtors system could do what it was supposed to do and they ensured that the testing of the new system was carried out in line with timescales outlined in the project implementation time chart. The accountants' technological skills, soft skills, position within the organisation and role in change programmes all facilitated the change management of this project.

It is essential to any project's success that a suitable project champion is appointed. The potential of the accountants for this role has been identified (Adam and O'Doherty, 2000; Doran and Walsh, 2004). The project champion in this case study was the head of finance. His status as a well-respected highranking in-house official, along with his excellent communication skills and solid accounting, budgeting and technology skills, made him an ideal project champion. It was important that the champion had this status. The SEO (Finance) confirmed this, stating that:

It was necessary to have the head of finance as project champion as he is the only person within Finance to achieve the resources for the project and influence top management support.

The project champion, as the advocate for change, must have status and strong business, communication and technology skills. It is evident from this case study that the head of finance within the council was a good fit for this role.

The existing literature highlights the requirement of an in-depth critique of the existing system (for example, Holland and Light, 1999; Nah and Delgado, 2006). In the council, the finance department played a key role in highlighting the problems with the debtors legacy systems and the need for a new integrated system. It carried out an analysis of the existing debtors legacy systems and the JDE AR module by speaking with key users, the ICT department and the other staff of the finance department. This helped highlight the problems of the legacy systems which were then documented by the SEO (Finance) and the accountants. Without this information the same problems with regards to the debtors legacy systems may have been repeated. This information helped provide the council with a clear vision of what the centralised debtors system should and should not do.

\section{CONCLUSION}

This case study finds that the ten critical success factors identified in the literature were present in this successful implementation. More importantly, this study demonstrates the substantial impact the accountants had in each of these factors. The obvious influence of the accountants in the implementation of an integrated system is to assist by the provision of information on the accounts layout, financial accounting requirements and customer account details. If this did not exist, the new system would not meet the financial reporting requirements and would 
have to be adapted to meet these requirements later. However, this research explored the need for a much more comprehensive involvement by the accountants. The researchers thought they would have to delve to find how the accountants fit into each of these criteria. Interestingly, they did not have to dig too far; the accountants initiated, led or championed every step of the implementation process. More interestingly, their involvement was very much supported by top management and other members of the implementation team.

Top management support was present from the beginning to the end as the project was given priority by the heads of finance and ICT. It was the commitment of the head of finance that was most evident throughout the case study. He supported the project by providing his own commitment and was always willing to give it the human and financial resources required. This feeling of importance encouraged the dedication of all of the staff to give it the time and attention necessary to make it a success. The head of finance justified the investment as part of a modernisation phase within the council. He believed it was critical to improve the efficiency and customer focus of the organisation.

Armed with business knowledge and communication and presentation skills, the accountants prepared and communicated the business vision to all the stakeholders of the project. Skilled cross-functional teams were set up, comprised of top management members, members of the finance department and ICT department, key users and members of the vendor development and implementation team. It was their ability to work as part of a multi-skilled team, to bring their financial and analytical expertise to the team and to represent the team when necessary, that made the accountants crucial members of each of the teams. Also, their absence in another system's implementation in the council, two years earlier, had resulted in costly and time-consuming modifications to the system after its implementation.

It was their knowledge and appreciation of the importance of planning and control that gave accountants the strength to be an important influence in implementing well-developed work and resource plans. The accountants, in particular, had an excellent working relationship with the vendor. This relationship was made possible by the business and technological knowledge of the accounting team. They knew what was required of the new system and they had the terminology to inform the vendor of these requirements.

The council carried out business process re-engineering prior to and during the systems implementation. The SEO (Finance) and the accountants were the key figures involved in examining these processes. The accountants were in a position to highlight the value-adding activities and the non-value-adding activities due to their close working relationship with the business units and their experience in correcting the mistakes of a previous system's implementation.

The change within the council due to the implementation of the new centralised debtors system was well managed and the accountants played a valuable role in managing that change. The accountants were instrumental in providing back-up support to the trainers. They assisted in training the users and in answering any questions they had. Again, their knowledge of accounting and the business gave the accountants the capability to achieve this. 
The project was championed by the head of finance. As the council had failed on a previous system's implementation due to lack of 'finance' input, it was strongly felt that the new centralised debtors system would be best championed by a finance person with both authority and accounting skills.

A critique of the old legacy systems, carried out by the finance department, highlighted all of the problems and shortfalls of the old systems. Due to the accountants' close working relationship with the users they had a clear knowledge of what the new centralised debtors system should be able to do, leaving the problems of the debtors legacy systems behind.

This case study highlighted the considerable impact the accountants had in each of the ten critical success factors. The involvement of the accountants in each of the ten critical success factors meant that their financial, analytical, communication, team-playing, leadership and technological skills, and business acumen, could be utilised to make the implementation of the new system a success. Of course the accountants on their own could not be responsible for the implementation of an integrated system, but their involvement as champions and team players was vital to the successful implementation of this new system.

\section{REFERENCES}

Adam, F. and O'Doherty, P. (2000). Lessons from Enterprise Resource Planning Implementations in Ireland - Towards Smaller and Shorter ERP Projects, Journal of Information Technology, Vol. 15, No. 4, pp. 305-316.

Allott, A., Weymouth, P. and Claret, J. (2001). Transforming the Profession: Management Accounting is Changing, in IFAC (Financial Management Accounting Committee) (ed.), A Profession Transforming: From Accounting to Management, New York, NY: IFAC.

Bhimani, A. (2003). Digitization and Accounting Change, in A. Bhimani (ed.), Management Accounting in the Digital Economy, Oxford: Oxford University Press.

Bingi, P., Sharma, M. and Godla, J. (1999). Critical Issues Affecting an ERP Implementation, Information Systems Management, Vol. 16, No. 3, pp. 7-14.

Botta-Genoulaz, V. and Millet, P.A. (2006). An Investigation into the Use of ERP Systems in the Service Sector, International Journal of Production Economics, Vol. 99, Nos. 1-2, pp. 202-221.

Caglio, A. (2003). Enterprise Planning Systems and Accountants: Towards Hybridization?, European Accounting Review, Vol. 12, No. 1, pp. 123-153.

Carswell, A. (2002). The IT Factor, Australian CPA, Vol. 72, No. 9, pp. 52-55.

Chenhall, R.S. and Langfield-Smith, K. (1998). Factors Influencing the Role of Management Accounting in the Development of Performance Measures within Organizational Change Programs, Management Accounting Research, Vol. 9, No. 4, pp. 361-386.

Davenport, T. (1998). Putting the Enterprise into the Enterprise System, Harvard Business Review, July-August, pp. 121-131.

Davenport, T. (2000). Mission Critical: Realising the Promise of Enterprise Systems, Boston, MA: Harvard Business School Press. 
Dempsey, S. and Vance, R. (2006). Advances in Information Technology Enhancing the Profile of the Management Accountant, Irish Business Journal, Vol. 2, No. 1, pp. 37-42.

Doran, J. and Walsh, C. (2004). The Effect of Enterprise Resource Planning (ERP) Systems on Accounting Practices in Companies in Ireland, Irish Accounting Review, Vol. 11, No. 2, pp. 17-34.

El Sayed, H. (2006). ERPs and Accountants' Expertise: The Construction of Relevance, Journal of Enterprise Information Management, Vol. 19, No. 1, pp. 83-96.

Granlund, M. and Malmi, T. (2002). Moderate Impact of ERPS on Management Accounting: A Lag or Permanent Outcome?, Management Accounting Research, Vol. 13, No. 3, pp. 299-321.

Granlund, M. and Mouritsen, J. (2003). Introduction: Problematizing the Relationship between Management Control and Information Technology, European Accounting Review, Vol. 12, No. 1, pp. 77-83.

Gurd, B., Smith, M. and Swaffer, A. (2002). Factors Impacting on Accounting Lag: An Explanatory Study of Responding to TQM, The British Accounting Review, Vol. 34, No. 3, pp. 205-221.

Halachmi, A. and Bovaird, T. (1997). Process Re-Engineering in the Public Sector: Learning Some Private Sector Lessons, Technovation, Vol. 17, No. 5, pp. 227-235.

Holland, C. and Light, B. (1999). A Critical Success Factors Model for ERP Implementation, IEEE Software, May/June, Vol. 16, No. 3, pp. 30-35.

Hunter, N. (2005). C\&AG Criticises Running of PPARS, IrishHealth.com, 13 December 2005, available at: <http://www.irishhealth.com/article.html?id=8659>, accessed 5 May 2006.

Hunton, J. (2002). Blending Information and Communication Technology with Accounting Research, Accounting Horizons, Vol. 16, No. 1, pp. 55-67.

Hyvonen, T. (2003). Management Accounting and Information Systems: ERP versus BoB, European Accounting Review, Vol. 12, No. 1, pp. 155-173.

Kavanagh, S. and Hoekstra, J. (2004). ERP Market Dynamics for Midsize Governments, Government Finance Review, Vol. 20, No. 6, pp. 11-16.

Kumar, V., Maheshwari, B. and Kumar, U. (2002). ERP Systems Implementations: Best Practices in Canadian Government Organizations, Government Information Quarterly, Vol. 19, No. 2, pp. 147-172.

Legare, T. (2002). The Role of Organizational Factors in Realizing ERP Benefits, Information Systems Management, Vol. 19, No. 4, pp. 21-42.

Loh, T.C. and Koh, S.C.L. (2004). Critical Elements for a Successful Enterprise Resource Planning Implementation in Small- and Medium-Sized Enterprises, International Journal of Production Research, Vol. 42, No. 17, pp. 3433-3455.

Madden, M. and Miranda, R. (1998). Contracting for Enterprise Financial Software: The Methodology of Parallel Negotiations, Government Finance Review, Vol. 14, No. 5, pp. 33-39.

Manganelli, R.L. and Klein, M.M. (1994). A Framework for Re-Engineering, Management Review, Vol. 1, No. 6, pp. 10-12.

Miranda, R. (1999). The Rise of ERP Technology in the Public Sector, Government Finance Review, Vol. 15, No. 4, pp. 9-17.

Motwani, J., Subramanian, R. and Gopalakrishna, P. (2005). Critical Factors for Successful ERP Implementation: Exploratory Findings from Four Case Studies, Computers in Industry, Vol. 56, No. 6, pp. 529-544. 
How Influential Are Accountants in the Implementation of an Integrated System?

Nah, F. and Delgado, S. (2006). Critical Success Factors for Enterprise Resource Planning Implementations and Upgrade, Journal of Computer Information Systems, Vol. 46, No. 5, pp. 99-113.

Nah, F., Zuckweiler, K.M. and Lee-Shang Lau, J. (2003). ERP Implementation: Chief Information Officers' Perceptions of Critical Success Factors, Journal of Human-Computer Interaction, Vol. 16, No. 1, pp. 5-22.

O'Mahony, A. and Doran, J. (2008). The Changing Role of Management Accountants; Evidence from the Implementation of ERP Systems in Large Organisations, International Journal of Business and Management, Vol. 3, No. 8, pp. 109-115.

Pierce, B. and O'Dea, T. (2003). Management Accounting Information and the Needs of Managers: Perceptions of Managers and Accountants Compared, British Accounting Review, Vol. 35, No. 3, pp. 257-270.

Rikhardsson, P. and Kraemmergaard, P. (2006). Identifying the Impacts of Enterprise System Implementation and Use: Examples from Denmark, International Journal of Accounting Information Systems, Vol. 7, No. 1, pp. 36-49.

Scapens, R.W. and Jazayeri, M. (2003). ERP Systems and Management Accounting Change: Opportunities or Impacts? A Research Note, European Accounting Review, Vol. 12, No. 1, pp. 201-233.

Shanks, G., Parr, A., Hu, B., Thanasankit, T. and Seddon, P. (2000). Differences in Critical Success Factors in ERP Systems Implementation in Australia and China: A Cultural Analysis, Proceedings of the 8th European Conference on Information Systems, Vienna, paper 53, available from: <http:/ / aisel.aisnet.org/ecis2000/53>, accessed 1 March 2010.

Tsay, B. (1992). Accountants' Role in the Age of IT, CMA Magazine, Vol. 66, No. 8, pp. 24-26.

Umble, E.J. and Umble, M. (2002). Avoiding ERP Implementation Failure, Industrial Management, Vol. 44, No. 1, pp. 25-33. 